\title{
Spectral and computational features of the binding between riparins and human serum albumin
}

\author{
Cintia Ramos Camargo a , Ícaro Putinhon Caruso b , Stanley Juan Chavez Gutierrez ${ }^{c}$, Marcelo Andres Fossey a,b, \\ José Maria Barbosa Filho ${ }^{\mathrm{d}}$, Marinônio Lopes Cornélio ${ }^{\mathrm{a}, \mathrm{b}, *}$ \\ a Departamento de Física, Instituto de Biociências, Letras e Ciências Exatas (IBILCE), UNESP, Rua Cristóvão Colombo 2255, CEP 15054-000, São José do Rio Preto, SP, Brazil

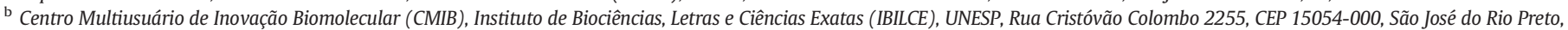 \\ SP, Brazil \\ c Departamento de Bioquímica e Farmacologia, Universidade Federal do Piauí (UFPI), CEP 64049-550 Teresina, PI, Brazil \\ d Laboratório de Tecnologia Farmacêutica (LTF), Universidade Federal da Paraíba (UFPB), Cidade Universitária, CEP 58051-900 João Pessoa, PB, Brazil
}

\section{A R T I C L E I N F O}

\section{Article history:}

Received 18 January 2017

Received in revised form 15 August 2017

Accepted 31 August 2017

Available online 8 September 2017

\section{Keywords:}

Riparin

Human serum albumin

Fluorescence

Binding density function

Drug displacement

Computational methods

\begin{abstract}
A B S T R A C T
The green Brazilian bay leaf, a spice much prized in local cuisine (Aniba riparia, Lauraceae), contains chemical compounds presenting benzoyl-derivatives named riparins, which have anti-inflammatory, antimicrobial and anxiolytic properties. However, it is unclear what kind of interaction riparins perform with any molecular target. As a profitable target, human serum albumin (HSA) is one of the principal extracellular proteins, with an exceptional capacity to interact with several molecules, and it also plays a crucial role in the transport, distribution, and metabolism of a wide variety of endogenous and exogenous ligands. To outline the HSA-riparin interaction mechanism, spectroscopy and computational methods were synergistically applied. An evaluation through fluorescence spectroscopy showed that the emission, attributed to Trp 214, at $346 \mathrm{~nm}$ decreased with titrations of riparins. A static quenching mechanism was observed in the binding of riparins to HSA. Fluorescence experiments performed at 298,308 and $318 \mathrm{~K}$ made it possible to conduct thermodynamic analysis indicating a spontaneous reaction in the complex formation $(\Delta G<0)$. The enthalpy-entropy balance experiment with a molecular modeling calculation revealed that hydrophobic, hydrogen bond and non-specific interactions are present for riparin IIII with HSA. The set of results from fractional fluorescence changes obtained through Schatchard was inconclusive in establishing what kind of cooperativity is present in the interaction. To shed light upon the HSA-riparins complex, Hill's approach was utilized to distinguish the index of affinity and the binding constant. A correspondence between the molecular structures of riparins, due to the presence of the hydroxyl group in the B-ring, with thermodynamic parameters and index of affinity were observed. Riparin III performs an intramolecular hydrogen bond, which affects the Hill coefficient and the binding constant. Therefore, the presence of hydroxyl groups is capable of modulating the interaction between riparins and HSA. Site marker competitive experiments indicated Site I as being the most suitable, and the molecular modeling tools reinforced the experimental results detailing the participation of residues.
\end{abstract}

(C) 2017 Elsevier B.V. All rights reserved.

\section{Introduction}

The Lauraceae family is considered to be one of the most fundamental families belonging to the Magnoliophyta division, having become widely distributed throughout tropical and subtropical regions, being composed at approximately 52 genera and 3000 species [1]. Lauraceae are utilized in papermaking, carpentry, construction, perfumery (essential oil), chemicals and folk medicine [2]. Different species of this family

\footnotetext{
* Corresponding author at: Departamento de Física, Instituto de Biociências, Letras e Ciências Exatas (IBILCE), UNESP, Rua Cristóvão Colombo 2255, CEP 15054-000 São José do Rio Preto, SP, Brazil.

E-mail address: mario@ibilce.unesp.br (M.L. Cornélio).
}

are also known worldwide mainly for their use in cooking, such as bay leaf (Laurus nobilis) avocado (Persea americana) and cinnamon (Cinnamomum zeylanicu) [3].

Aniba riparia (Ness) Mez, popularly known in Brazil as louro, is a typical plant of the Amazon region [4], commonly used as a spice. Its fruits contain many different chemical components, such as flavonoids, neolignans, stirilpironas and alkamides [5]. Methyl ether of $N$-benzoyltyramine (riparin I, insert in Fig. 1a), methyl ether of $\mathrm{N}$-2-hydroxy-benzoyl-tyramine (riparin II, insert in Fig. 1b) and methyl ether of $\mathrm{N}$-2,6-dihydroxy-benzoyl-tyramine (riparin III, insert in Fig. 1c) have been isolated from the green fruit of this plant [6]. These molecules have important anti-inflammatory, antimicrobial and anxiolytic pharmacological effects, and great therapeutic potential [6,7]. 


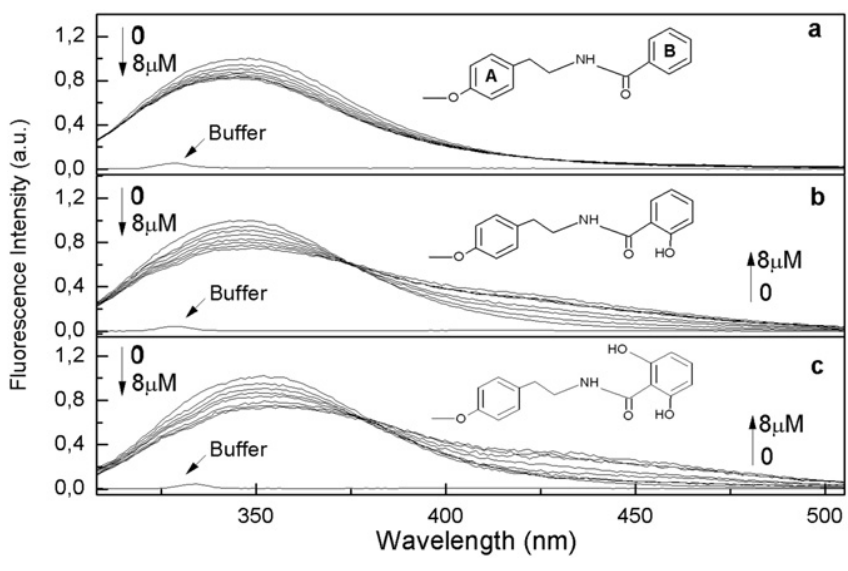

Fig. 1. Fluorescence emission spectra of HSA $(4 \mu \mathrm{M})$ at different concentrations ( 0 to $8 \mu \mathrm{M})$ of (a) riparin I (b) riparin II and (c) riparin III at $298 \mathrm{~K}$. Inserts shows the correspondent molecular structure.

Riparin I, for example, demonstrated antinociceptive activity [8] and antianxiety effects in animal models [9]. Studies with riparin II revealed that it may inhibit directly or indirectly the activity, production or release of pro-inflammatory mediators involved in the generation of pain associated with inflammation [7], and produces significant antidepressant activity [10]. Riparin III, administered intraperitoneally or orally, also showed anxiolytic and antidepressant activity in rodents [1012]. Moreover, natural riparins showed antimicrobial activity in multidrug-resistant strains of Staphylococcus aureus [13]. However, the interactions of these benzoyl derivatives with specific molecular targets have not been fully understood.

As a profitable target, human serum albumin (HSA) is one of the most important and abundant proteins in the circulatory system. It is a 585-residue monomer and consists of three homologous domains (denoted I, II and III), each of which has two sub-domains, A and B, possessing common structural motifs [14]. HSA has an exceptional capacity to interact with many molecules, playing a crucial role in the transport, distribution, and metabolism of a wide variety of endogenous and exogenous ligands [15]. Site I and site II, located respectively in subdomains IIA and IIIA are two major ligand binding sites for small organic molecules. Recently, subdomain IB (site III) has been identified as the primary or secondary binding site for some compounds [16]. Structural features of compounds, specifically the number and configuration of hydroxyl radical on polyphenols, influence binding characteristics with this transport protein. The $-\mathrm{OH}$ moiety is also associated with the reactivity of aromatic molecules and is important for their biological activities [17-19].

In that sense, an investigation of the interaction between riparin I, II and III and HSA contributes to an understanding of the riparin-protein affinity, disposition, transportation and metabolism of these benzoyl-tyramines at molecular level. In the present study, fluorescence quenching was employed to probe the affinity of riparins to HSA under simulative physiological conditions. Particularly, the influence of the hydroxylation pattern, present in riparin II and III, on binding characteristics with HSA was analyzed, as was the specific binding site for each riparin on HSA. As part of the strategy to tackle the problem computational methods were applied with experimental parameters as references to perform the docking.

\section{Materials and Methods}

\subsection{Chemicals}

Riparins were isolated by one of our collaborators in pure form for the study. Human serum albumin, warfarin, ibuprofen, methyl orange, dibasic sodium phosphate, methanol and sodium chloride $(\mathrm{NaCl})$ were purchased from Sigma Aldrich Chemical Company (USA). All other chemicals were analytical grade and Milli-Q ultrapure water was used throughout the experiment. HSA was dissolved in a phosphate buffer solution of $50 \mathrm{mM}$ containing $\mathrm{NaCl}(150 \mathrm{mM}, \mathrm{pH}$ 7.0). The protein concentration was determined spectrophotometrically using the molar extinction coefficient of $36,500 \mathrm{M}^{-1} \mathrm{~cm}^{-1}$ at $280 \mathrm{~nm}$. Riparin I, riparin II and riparin III stock solutions were prepared in methanol with 23.8, 5.42 and $1.23 \mathrm{mM}$, respectively.

\subsection{Fluorescence Spectroscopy}

Fluorescence measurements were performed on a Varian Cary Eclipse fluorescence spectrophotometer equipped with $1.0 \mathrm{~cm}$ quartz cells and Carry Eclipse thermostat bath. Both excitation and emission slits were set at $5.0 \mathrm{~nm}$. The fluorescence spectra were recorded in the range of 300-505 $\mathrm{nm}$ and the excitation wavelength of $295 \mathrm{~nm}$ was chosen, since it provides excitation of the single tryptophan residue (Trp 214) and avoids absorption of tyrosine residues. All fluorescence intensities were corrected for the buffer and inner filter effects (Eq. (1)) [20-22].

$\mathrm{F}_{\text {corr }}=\mathrm{F}_{\text {obs }} \times \mathrm{e}^{\left(\mathrm{A}_{\mathrm{ex}}+\mathrm{A}_{\mathrm{em}}\right) / 2}$

$\mathrm{F}_{\text {corr }}$ and $\mathrm{F}_{\mathrm{obs}}$ are the fluorescence intensity corrected and observed and $A_{e x}$ and $A_{e m}$ are the absorbance of the system at the excitation and emission wavelengths, respectively.

In fluorescence quenching experiments, titration was performed by adding appropriate quantities of riparin I-III stock solution to the HSA solution $(2.0 \mathrm{~mL})$ at constant concentrations of $2.0,4.0$ and $8.0 \mu \mathrm{M}$. In experiments to determine the Stern-Volmer constant and Binding Data Analysis the HSA concentration remained constant at $4.0 \mu \mathrm{M}$, and the riparin concentrations varied from 0 to $8 \mu \mathrm{M}$ with increments of $1.0 \mu \mathrm{M}$ at 298,308 and $318 \mathrm{~K}$. For the binding density function (BDF) method, titration was performed at HSA concentrations of 2.0 and 8.0 $\mu \mathrm{M}$ and the range of riparin concentrations were $0-12 \mu \mathrm{M}$, with increments of $1.0 \mu \mathrm{M}$, at $298 \mathrm{~K}$. The effect of methanol as a co-solvent was verified by adding aliquots to the HSA solution $(2.0,4.0$ and $8.0 \mu \mathrm{M}$, at $298 \mathrm{~K}$ ) within the volume variation of previous titrations. The final volume of methanol in the buffer was $<1 \%$, in all experiments.

\subsection{Site Marker Competitive Experiments}

Competitive experiments were carried out by the use of warfarin, ibuprofen and methyl orange which bind to site I, site II, and site III, respectively $[16,23]$. The ratio of site marker to HSA solution was $1: 1$ (4.0 $\mu \mathrm{M}$ each). After $1 \mathrm{~h}$ incubation of the mixtures, amounts of riparin I, II and III solution, varying from 0 to $10 \mu \mathrm{M}$ with increments of $1.0 \mu \mathrm{M}$, were added to each of HSA-marker solutions as previously. The fluorescence spectra were recorded at $298 \mathrm{~K}$ under the same experimental conditions described above.

\subsection{Ab Initio Calculation}

The Gaussian 09 program [24] provided by Núcleo de Computação Científica da Universidade Estadual Paulista (NCC/GridUNESP) was applied to the calculation of riparin structures. The optimized geometry was calculated in the gas phase with riparin molecules isolated by using DFT/B3LYP/6-31G(d,p) method. The next step, the vibrational frequency calculation, was performed to check the optimized riparin molecules. The molecular electrostatic potential (MEP) map was calculated to investigate the distribution of charge density on the molecular surface of riparin I, II and III. 


\subsection{Molecular Modeling Calculation}

The crystal structure of HSA (PDB ID: 1AO6) [25] was obtained from the Protein Data Bank. The three-dimensional structure of riparin molecules was obtained from Gaussian 09 program [24]. AutoDockTools (ADT) [26] was used to prepare the HSA and riparins by merging nonpolar hydrogen atoms, adding partial charges and atom types. The ligand rigid root was generated automatically, defining all possible rotatable bonds and torsions them as active for riparins, except for riparin III, whose C3-C21 bond was set as non-rotatable, keeping the intramolecular hydrogen bond between the hydrogen atom $\mathrm{H} 22$ from hydroxyl and the oxygen $\mathrm{O} 3$ from carbonyl group. Grid maps were generated with $0.375 \AA$ spacing and dimensions of $60 \times 60 \times 60$ points by the AutoGrid 4.2 program [27], centered on site 1 of the HSA structure. The AutoDock 4.2 program [27] was employed to study the binding site between riparins and HSA by applying the Lamarckian Genetic Algorithm (LGA) for minimization using a number of energy evaluations of 2.5 million, a population size of 150 and root-square-mean deviation (RMSD) tolerance for cluster analysis of $2.0 \AA$. Random starting positions on the entire protein surface and random orientations were used for the ligands. For each docking simulation, 100 different conformers were generated. The structural representation was prepared using PyMOL [28], and the map of interaction was calculated using LigPlot [29].

\section{Results and Discussion}

\subsection{Fluorescence Quenching of HSA Upon Addition of Riparins}

Intrinsic fluorescence spectra of HSA at different concentrations of riparin I, II and III are shown in Fig. 1a, b, and c, respectively. It can be seen that, upon excitation at $295 \mathrm{~nm}$, HSA exhibits a maximum emission peak at $346 \mathrm{~nm}$, solely contributed by tryptophan (Trp 214) residue in HSA. The HSA emission decreased with the increment of riparin concentration, indicating that the interaction of benzoyl-tyramines quenched the intrinsic fluorescence of HSA. Further, upon the addition of riparin II and III, two isosbestic point formations were noted at 364 and $369 \mathrm{~nm}$, respectively. This phenomenon indicates the existence of benzoyl-tyramine derivatives bound to HSA at equilibrium [30]. Also, riparins II and III showed a clear second peak, which increases with titration, and corresponds to the riparin signals at 413 and $422 \mathrm{~nm}$, respectively [31]; these contributions were subtracted from the HSA fluorescence signal.

\subsection{Fluorescence Quenching Mechanisms}

Fluorescence quenching mechanisms are classified as being either dynamic or static. The former is due to collision between the quencher and fluorophore and the latter, to the formation of a non-fluorescent ground state complex. These two mechanisms may be discriminated in response to temperature. The bound complexes, for static quenching, become more unstable as temperature increases and quenching constants decrease; the opposite behavior is observed for dynamic quenching. The quenching mechanism is currently analyzed by the Stern-Volmer model [21]:

$\frac{\mathrm{F}_{0}}{\mathrm{~F}}=1+\mathrm{K}_{\mathrm{q}} \tau_{0}[\mathrm{Q}]=1+\mathrm{K}_{\mathrm{SV}}[\mathrm{Q}]$

$F_{0}$ and $F$ represent the fluorescence intensity before and after quencher addition, respectively; $\mathrm{K}_{\mathrm{q}}$ is the biomolecular quenching constant; $\tau_{0}$ is the average fluorescence lifetime of the molecule without a quencher; generally $10^{-8} \mathrm{~s}[21]$; [Q] is the quencher concentration, and $\mathrm{K}_{\mathrm{sV}}$ is the Stern-Volmer constant, which can be determined by linear regression of a plot of $F_{0} / F$ against $[Q]$. Stern-Volmer plots for the fluorescence quenching of HSA $(4 \mu \mathrm{M})$ in the presence of riparin I-III at 298, 308 and $318 \mathrm{~K}$ are shown in Fig. 2. According to the linear

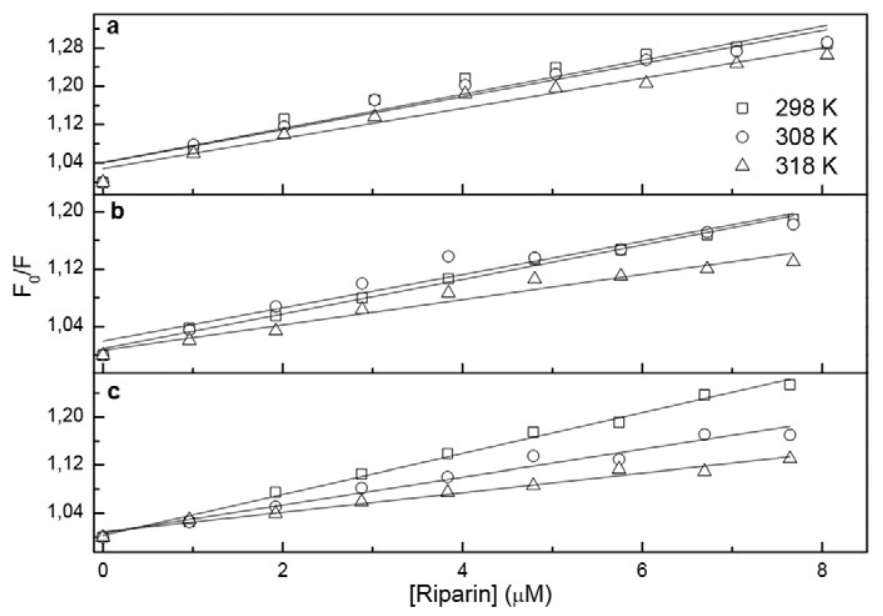

Fig. 2. Stern-Volmer plots for the fluorescence quenching of $\mathrm{HSA}(4 \mu \mathrm{M})$ in the presence of (a) riparin I (b) riparin II and (c) riparin III at 298, 308 and $318 \mathrm{~K}$.

adjustment for the experimental data the slope of the curves indicates a decrement as temperature rises. Such a response to temperature corresponds to a static quenching mechanism.

\subsection{Binding Constants}

The binding constants $\left(\mathrm{K}_{\mathrm{a}}\right)$ and the number of binding sites $(\mathrm{n})$ per protein can be obtained by Double-logarithm plot [32]:

$\log \left(\frac{\mathrm{F}_{0}-\mathrm{F}}{\mathrm{F}}\right)=\operatorname{nlog} \mathrm{K}_{\mathrm{a}}-\operatorname{nlog}\left(\frac{1}{\left([\mathrm{Q}]-\frac{\left(\mathrm{F}_{0}-\mathrm{F}\right)}{\mathrm{F}_{0}}[\mathrm{P}]\right)}\right)$

where $[\mathrm{P}]$ is the protein concentration. Double plots are shown in Fig. 3 and the values of $\mathrm{K}_{\mathrm{b}}$ and $\mathrm{n}$ are listed in Table 1 . The constants represent phenomenological parameters, with $n$ indicating the quantity of binding sites and $\mathrm{K}_{\mathrm{a}}$ their binding affinity [33]. The values of $\mathrm{n}$ are approximately 1.0 and $\mathrm{K}_{\mathrm{a}}$ the order of $10^{4} \mathrm{M}^{-1}$, which is a mild constant. The $\mathrm{K}_{\mathrm{b}}$ magnitude contains important features about the complex formation. It responds to temperature variation, assisting in the search for the forces that stabilize the complex [30]. Table 1 summarizes the $\mathrm{K}_{\mathrm{SV}}$, $\mathrm{K}_{\mathrm{q}}$ and $\mathrm{K}_{\mathrm{a}}$ constants.

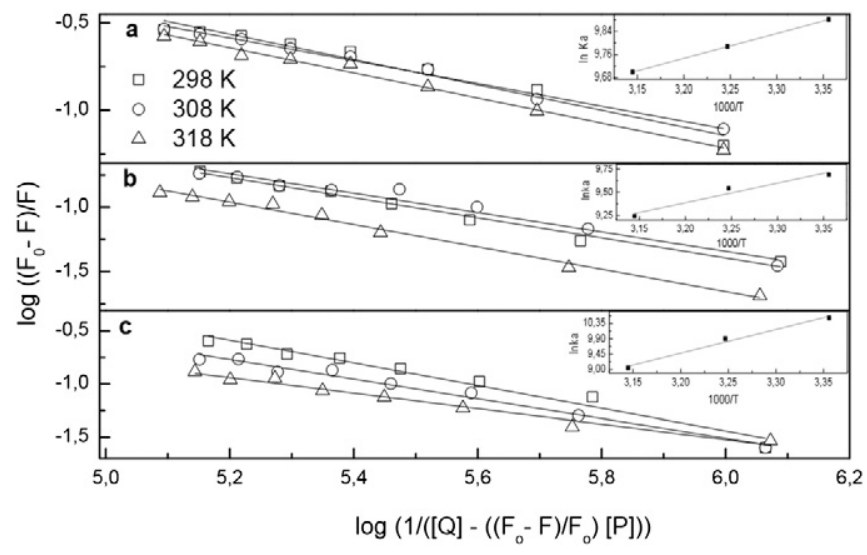

Fig. 3. Double-log plots for the fluorescence quenching of HSA ( $4 \mu \mathrm{M})$ in the presence of (a) riparin I (b) riparin II and (c) riparin III at 298, 308 and $318 \mathrm{~K}$. The inserts show the Van't Hoff plot. 
Table 1

Values of the Stern-Volmer constant $\left(\mathrm{K}_{\mathrm{SV}}\right)$ for tryptophan fluorescence quenching of HSA, biomolecular quenching constant $\left(\mathrm{K}_{\mathrm{q}}\right)$ binding constants $\left(\mathrm{K}_{\mathrm{a}}\right)$ and binding site numbers (n) of the interaction between HSA and riparin I, II or III at 298,308 and $318 \mathrm{~K}$.

\begin{tabular}{llllll}
\hline Quencher & $\mathrm{T}(\mathrm{K})$ & $\mathrm{K}_{\mathrm{SV}}\left(\times 10^{4} \mathrm{M}^{-1}\right)$ & $\mathrm{K}_{\mathrm{q}}\left(\times 10^{12} \mathrm{M}^{-1} \mathrm{~s}^{-1}\right)$ & $\mathrm{K}_{\mathrm{a}}\left(\times 10^{4} \mathrm{M}^{-1}\right)$ & $\mathrm{n}$ \\
\hline Riparin I & 298 & 3,56 & 3,56 & 1,95 & 0,62 \\
& 308 & 3,45 & 3,45 & 1,78 & 0,62 \\
& 318 & 3,14 & 3,14 & 1,63 & 0,66 \\
Riparin II & 298 & 2,41 & 2,41 & 1,75 & 0,78 \\
& 308 & 2,31 & 2,31 & 1,64 & 0,75 \\
& 318 & 1,76 & 1,76 & 1,24 & 0,88 \\
Riparin III & 298 & 3,41 & 3,41 & 4,28 & 1,04 \\
& 308 & 2,32 & 2,32 & 2,15 & 0,91 \\
& 318 & 1,63 & 1,63 & 0,77 & 0,72 \\
\hline
\end{tabular}

The correlation coefficient is $\geq 0,98$.

\subsection{Thermodynamic Parameters and Driven Forces}

In general, the driven forces between a small molecule and a protein include Van der Waals force, hydrogen bonding, electrostatic and hydrophobic interactions. The signs and magnitude of the thermodynamic parameters, enthalpy $(\Delta H)$, entropy $(\Delta S)$ changes and free energy $(\Delta G)$, of the binding reaction may indicate the types of binding along with the interaction [34]. According to the Van't Hoff analysis, if the enthalpy does not change significantly with the range of temperature experimentally applied, then the entropy value can be reached:

$$
\ln K_{\mathrm{a}}=-\frac{\Delta \mathrm{H}}{\mathrm{RT}}+\frac{\Delta \mathrm{S}}{\mathrm{R}}
$$

$\mathrm{K}_{\mathrm{a}}$ is the binding constant at the corresponding temperature and $\mathrm{R}$ is the gas constant. The Gibbs free energy is estimated according to the following relationship:

$\Delta \mathrm{G}=\Delta \mathrm{H}-\mathrm{T} \Delta \mathrm{S}$

The Van't Hoff plots for the binding of HSA to riparin I-III are shown as inserts in Fig. 3, which correspond to the thermodynamic parameters that are summarized in Table 2. The negative Gibbs free energy values calculated for all riparins mean that the interaction is a spontaneous process. The negative value for $\Delta \mathrm{H}$ and positive for $\Delta \mathrm{S}$ are determined for the riparin I and riparin II-HSA complexes, suggesting that the driving forces between these riparins with HSA are composed by non-specific interactions; while both negative values of $\Delta \mathrm{H}$ and $\Delta \mathrm{S}$ for the riparin III-HSA indicate that the van der Waals interactions and hydrogen bonds have an important contribution during the interaction process of riparin III with HSA [35].

\subsection{Site-selective Identification of Riparins on HSA}

HSA interacts reversibly with drugs which bind to one or more highaffinity sites with typical association constants in the range of $10^{4-} 10^{6} \mathrm{M}^{-1}$. Pioneering studies by Sudlow and contributors [36]

Table 2

Thermodynamic parameters of HSA-ligand complex at 298, 308 and $318 \mathrm{~K}$.

\begin{tabular}{lllll}
\hline Quencher & $\mathrm{T}(\mathrm{K})$ & $\Delta \mathrm{H}\left(\mathrm{kJ} \mathrm{mol}^{-1}\right)$ & $\Delta \mathrm{S}\left(\mathrm{J} \mathrm{mol}^{-1}\right)$ & $\left.\Delta \mathrm{G}(\mathrm{kJ} \mathrm{mol})^{-1}\right)$ \\
\hline Riparin I & 298 & -7.14 & 58,15 & $-24,47$ \\
& 308 & & & $-25,05$ \\
\multirow{2}{*}{ Riparin II } & 318 & & 31,16 & $-25,63$ \\
& 298 & $-14,91$ & & $-24,19$ \\
& 308 & & $-135,60$ & $-24,51$ \\
Riparin III & 318 & & & $-26,56$ \\
& 398 & $-66,97$ & & $-25,20$ \\
& 318 & & & $-23,85$ \\
\hline
\end{tabular}

The correlation coefficient is $\geq 0,99$. applying the fluorescent probe displacement method showed that most drugs bind with high affinity to two specific drug binding sites, namely, site I (subdomains IIA, also called the warfarin binding site) and site II (subdomains IIIA, the ibuprofen binding site) [37]. However, some drug binding sites differ from sites I and II, identified as subdomains that are neither IIA nor IIIA $[38,39]$; methyl orange binds in site III (subdomain IB) [30]. The binding locations are commonly identified applying standard ligands, such as warfarin, ibuprofen and methyl orange, which probe sites I, II and III, respectively.

Thus, the competition of riparins with warfarin, ibuprofen and methyl orange was investigated. The fluorescence quenching rate $(\mathrm{F} /$ $F_{0}$ ) in the presence and absence of markers was compared and is presented in Fig. 4. The difference in the quenching rate in the presence of the warfarin, when compared with the quenching rate with no marker, is remarkable. This is a strong indication that the riparins compete for the same site of warfarin and bind to HSA chiefly in site I.

\subsection{Binding Density Function Method}

In order to ensure a more realistic approach regarding the complex formation and stability a second experimental method was applied. Equilibrium binding isotherms, for a ligand binding to a macromolecule (protein), represent the relationship between total average binding density $\Sigma v_{\mathrm{i}}$ and the free ligand concentration $[\mathrm{L}]_{\text {free }}[40]$.

The fractional fluorescence change $\left(\Delta \mathrm{F}_{\mathrm{obs}}\right)$ is the fluorescence signal normalized to the initial fluorescence of the free macromolecule:

$\Delta \mathrm{F}_{\mathrm{obs}}=\frac{\mathrm{F}_{\mathrm{obs}}-\mathrm{F}_{\text {free }}[\mathrm{M}]_{\mathrm{T}}}{\mathrm{F}_{\text {free }}[\mathrm{M}]_{\mathrm{T}}}$

$F_{\text {obs }}$ is the observed spectroscopic signal, $F_{f r e e}[M]_{T}$ the observed spectroscopic signal for a free macromolecule in the absence of a ligand and the total concentration of macromolecules. The values of $\Delta \mathrm{F}_{\mathrm{obs}}$ were plotted as a function of the logarithm of the total ligand concentration $[\mathrm{L}]_{\mathrm{T}}$ (see Fig. 5). At two different total concentrations of macromolecule $\left([\mathrm{M}]_{\mathrm{T} 1}\right.$ and $[\mathrm{M}]_{\mathrm{T} 2}$ ) the observed value of $\Delta \mathrm{F}_{\mathrm{obs}}$ is equal, so that $\Sigma v_{\mathrm{i}}$ and $[\mathrm{L}]_{\text {free }}$ must be the same for both titration curves.

In order to find the same value of $\Delta \mathrm{F}_{\mathrm{obs}}$ an interpolation procedure was performed using a sigmoid adjustment for both macromolecule concentrations. According to the mass conservation equation, (Eq. (7)), for the total concentration protein, $[\mathrm{L}]_{\text {free }}$ and $\Sigma v_{i}$ can be determined by the linear regression of a plot of $[\mathrm{L}]_{\mathrm{T}}$ against $[\mathrm{M}]_{\mathrm{T}}$ (see insert in Fig. 5) [41].

$[\mathrm{L}]_{\mathrm{T}}=[\mathrm{L}]_{\text {free }}+\Sigma v_{\mathrm{i}}[\mathrm{M}]_{\mathrm{T}}$

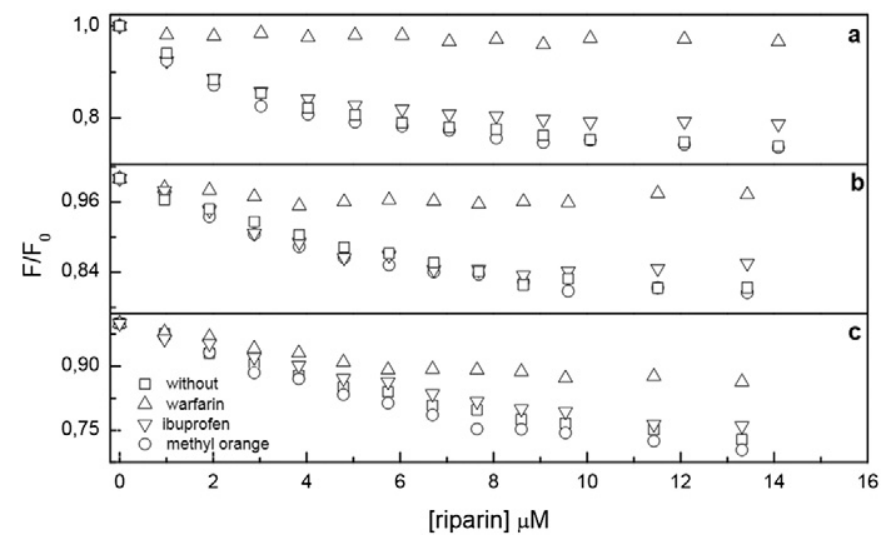

Fig. 4. Fluorescence quenching rate of HSA at different concentrations $(0-10 \mu \mathrm{M})$ of (a) riparin $\mathrm{I}$, (b) riparin II and (c) riparin III in the absence and presence of site markers (warfarin, methyl orange or ibuprofen). [HSA] $=[$ marker $]=4 \mu \mathrm{M}, \mathrm{pH} 7$ and $298 \mathrm{~K}$. 


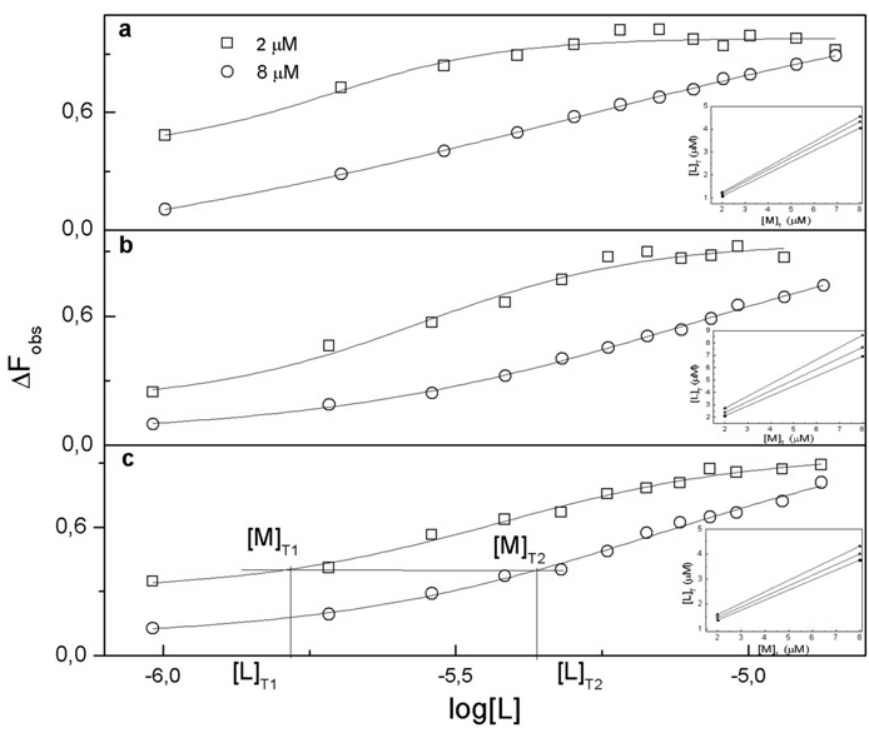

Fig. 5. Semilogarithmic plots of fluorescence titration of (a) riparin I (b) riparin II and (c) riparin III with HSA at two different protein concentrations at $298 \mathrm{~K}$. The vertical lines indicates the total ligand concentrations $[\mathrm{L}]_{\mathrm{T} 1}$ and $[\mathrm{L}]_{\mathrm{T} 2}$ at the same selected value of the observed fluorescence change, marked by the horizontal line, $\Delta \mathrm{F}_{\mathrm{obs}}$, at which the total average of ligand binding is the same for both titration curves. Inserts corresponds to only three sets of concentration pairs $\left(\mathrm{L}_{\mathrm{T}} ; \mathrm{M}_{\mathrm{T}}\right)$ to exemplify the utilization of Eq. (6) obtaining $\Sigma v_{\mathrm{i}}$ and $[\mathrm{L}]_{\text {free }}$ values.

Once $\Sigma v_{\mathrm{i}}[\mathrm{L}]_{\text {free }}$ and $[\mathrm{L}]_{\text {free }}$ were obtained the Scatchard plot $\left(\Sigma v_{\mathrm{i}} /\right.$ $[L]_{\text {free }}$ versus $\Sigma v_{\mathrm{i}}$ ) was constructed and is presented in Fig. 6.

The Schatchard plots show a concave shape with a 'tail' near the saturation for riparin I and II, Fig. 6a and Fig. 6b, respectively. The concavity shape in these cases indicates that the process of ligand binding may have a mix of negative and positive cooperativity. For riparin III, Fig. $6 \mathrm{c}$ shows that the elongation on the concavity is shorter which may be considered a negative cooperativity. The response profiles of the Schatchard plots are inconclusive so it is necessary to resort to Hill's formalism to elucidate the interaction mechanism. Hill relationship was used according to Eq. (8) [42-44].

$\sum \mathrm{v}_{\mathrm{i}}=\frac{\mathrm{n}_{\mathrm{H}}\left(\mathrm{K}[\mathrm{L}]_{\text {free }}\right)^{\mathrm{n}_{\mathrm{H}}}}{1+\left(\mathrm{K}[\mathrm{L}]_{\text {free }}\right)^{\mathrm{n}_{\mathrm{H}}}}$

The results obtained according to Eq. (8) are summarized in the Table 3. The Hill coefficient $\left(n_{H}\right)$ may be interpreted as the index of affinity between the ligand and the macromolecule, and $\mathrm{K}$ the binding constant. The values of $\mathrm{n}_{\mathrm{H}}$ obtained to Riparin I, free of OH group at Bring, is close to Riparin II, which has the first $\mathrm{OH}$ group positioned at $\mathrm{C} 2$ carbon atom, both presented a mild association constant. From the thermodynamic evaluation Riparins I and II while interacting with HSA performed a spontaneous reaction $(\Delta G<0)$, presented an enthalpic-entropic balance revealing resemblance between hydrophobic and non-specific interactions. The results presented for Riparin III, which has the second $\mathrm{OH}$ group positioned at $\mathrm{C} 6$ carbon atoms, deviated from the previous results. It was found that the index of affinity was the lowest of all. The association constant drops by a factor of two in comparison with riparin II, and the energetic balance, although favorable $(\Delta \mathrm{G}<0)$, the enthalpy-entropic balance showed an important changes in signal and magnitude of the entropic contribution, which becomes negative, perhaps an indication of non-specific interaction enhancement not detected previously. The capacity of performing hydrogen bonds is expected for the ligand while interacting with protein [18], unless such an interaction preferentially occurs as intramolecular mode, which affects the binding constant. According to the literature [45], riparin III is able to perform intramolecular hydrogen bounds between one of the $\mathrm{H}$ atom of the $\mathrm{OH}$ groups with the $\mathrm{O}$ atom of the $\mathrm{C}=\mathrm{O}$ group.

\subsection{Ab Initio Calculation}

The optimization and vibrational calculation performed for the riparins using the DFT/B3LYP/6-31G(d,p) method showed that the optimized structure is stable (global minimum on the potential energy surface), since no imaginary frequency is obtained. Some calculated bond distances, bond angles, and dihedral angles are presented in Table S1

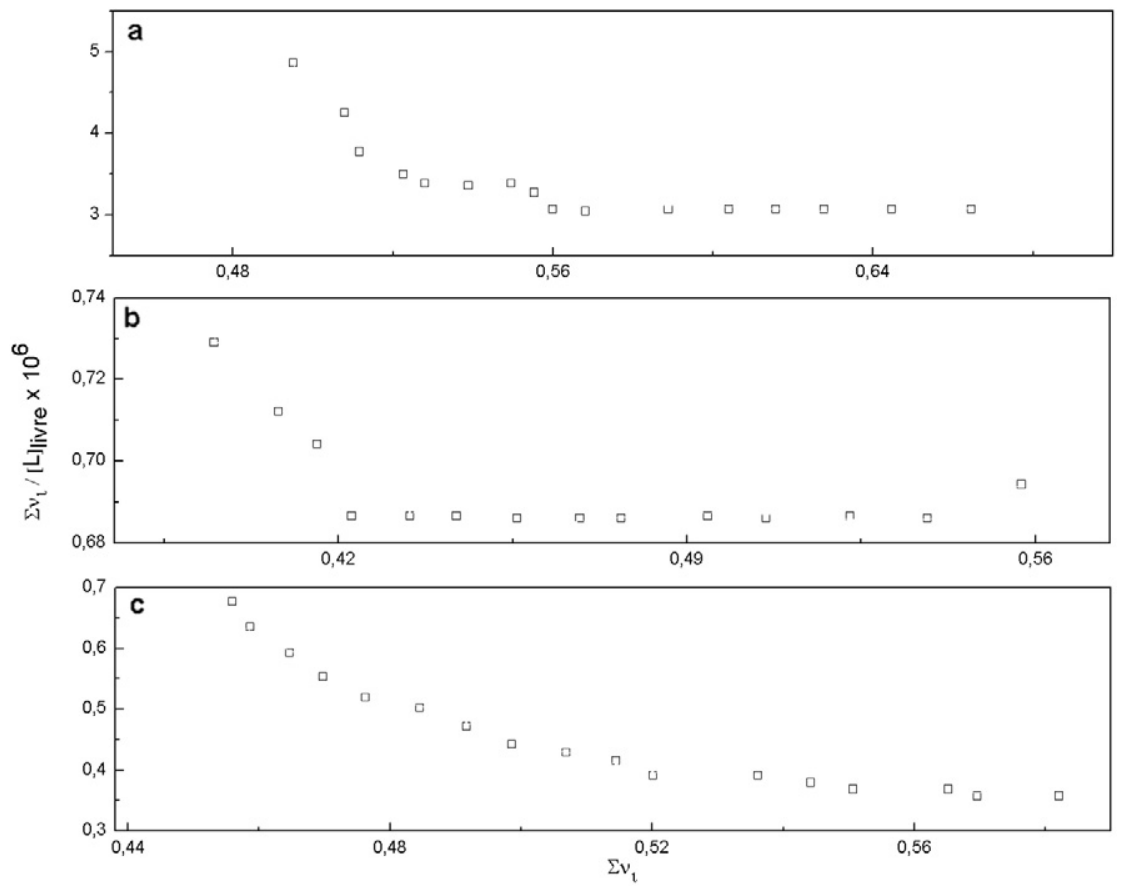

Fig. 6. Scatchard plots of (a) riparin I, (b) riparin II and (c) riparin III with HSA. 
Table 3

Affinity index $\left(\mathrm{n}_{\mathrm{H}}\right)$ and binding constant $(\mathrm{K})$ obtained using Hill function for HSA-riparin I-III systems.

\begin{tabular}{lll}
\hline Quencher & $\mathrm{n}_{\mathrm{H}}$ & $\mathrm{K}\left(\mathrm{M}^{-1}\right)$ \\
\hline Riparin I & 5,9 & $4,03 \times 10^{6}$ \\
Riparin II & 6,1 & $1,25 \times 10^{6}$ \\
Riparin III & 3,4 & $5,57 \times 10^{5}$ \\
\hline
\end{tabular}

of Supplementary material. From the MEP of riparins (Supplementary material, Fig. S1) it is possible to note the existence of a neutral charge distribution on the planar faces of the rings of the molecule. A dense distribution of negative partial charges can also be seen near the 03 oxygen atom for riparin I, $\mathrm{O} 22$ atom for riparin II and III. On the other hand, a positive electrostatic potential is localized near the $\mathrm{H}^{\mathrm{N}}$ hydrogen atom in the riparins, and other regions of the molecules comparatively less dense near the hydrogen of C141 carbon atoms.

\subsection{Molecular Modeling Calculation}

The fluorescent probe displacement results were used to perform the molecular modeling calculations, positioning the riparin molecules at site I of HSA. The best theoretical binding energies $\left(\Delta G_{B}\right)$ for riparin I, II and III are $-29.8,-30.7$ and $-28.3 \mathrm{~kJ} \mathrm{~mol}^{-1}$, with corresponding theoretical binding constants of $1.7 \times 10^{5}, 2.4 \times 10^{5}$ and $9.0 \times 10^{4} \mathrm{M}^{-1}$ at $298 \mathrm{~K}$, respectively, which is very close to the trend found experimentally.

Fig. 7 summarizes the interaction between HSA and riparins from three different perspectives. At the top, Fig. 7A shows the tertiary structure of HSA with the location of the riparin molecules in its subdomain IIA ( site I), as well as the position of its single Trp214 residue. In the middle, Fig. 7B-D present in more detail the three-dimensional binding environment of riparin I, II and III at site I of HSA, respectively, showing the amino acid residues of the protein involved in the interaction with the riparins. At the bottom, Fig. 7E-G show the analysis of the non-covalent interactions at site I for riparin I, II and III, respectively, performed using LigPlot program [29].

On the left branch (Fig. 7E), Ser192, Lys 195, Lys199, Leu238, His242, Leu260, Ala261, Ser287, Ile290, and Ala291 residuesLeu198Trp214 Leu238Val344Pro447Val455 are involved in hydrophobic interactions with the riparin I. The Tyr150, Gln196 and Arg257 residues form hydrogen bonds with the ligand. The $\mathrm{OH}$ and $\mathrm{NH}$ group of Tyr150 and Arg257 side chain make up two hydrogen bonds with the 03 oxygen atom of riparin I, presenting formation distances of 2.47 and $3.04 \AA$, respectively. Such an oxygen atom presents the densest distribution of negative partial charge as can be seen in MEP of the molecule (Fig. S1A). The $\mathrm{NH}_{2}$

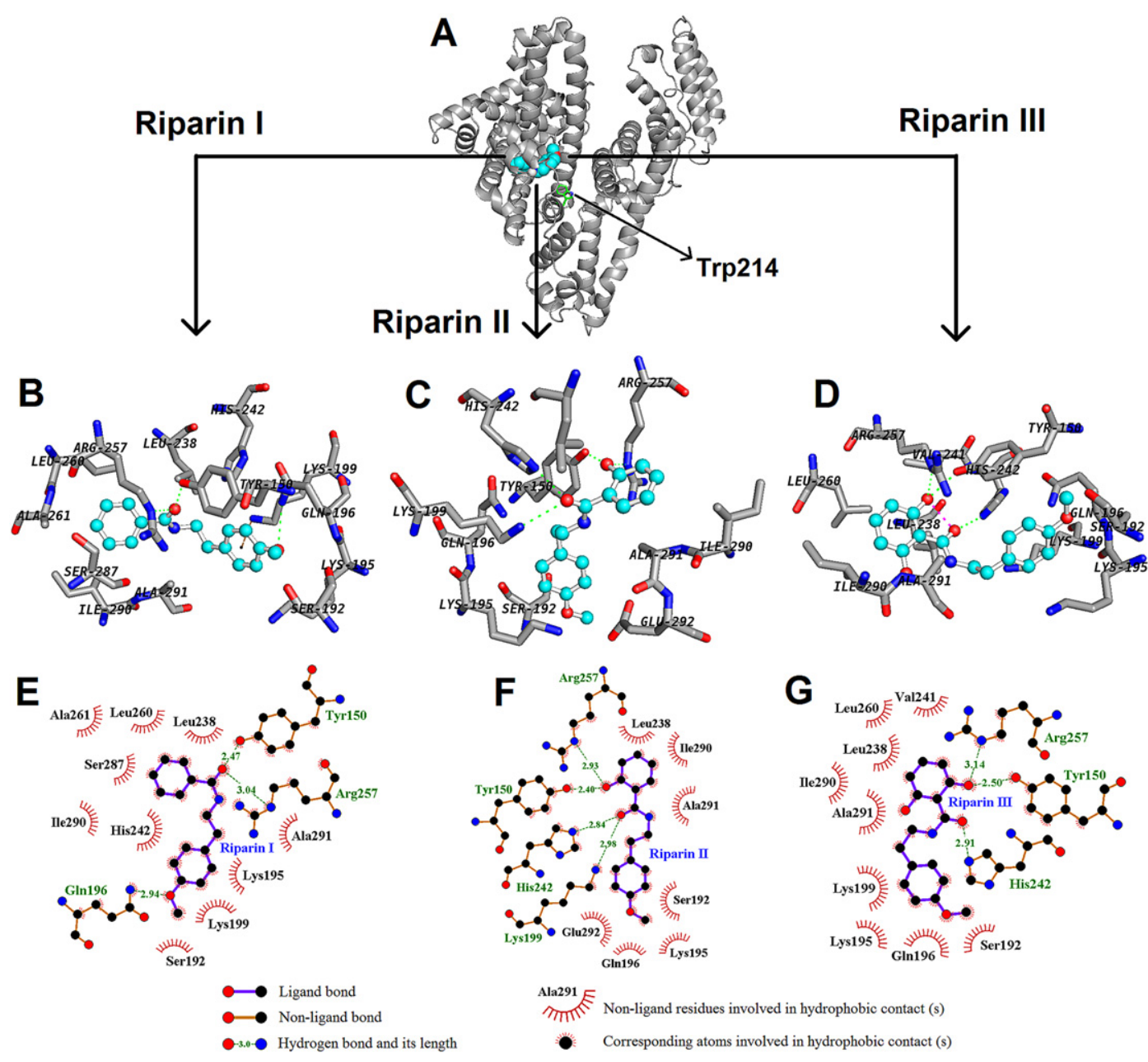

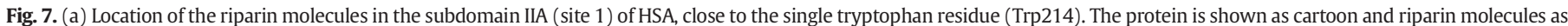

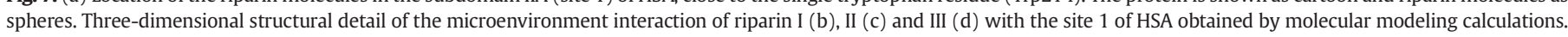

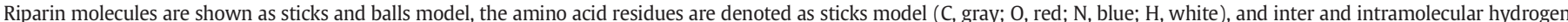

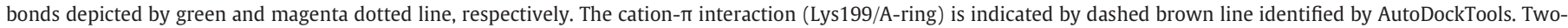

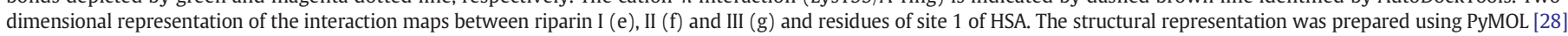
and the map of interactions was calculated using LigPlot [29]. 
group of the Gln196 side chain forms a hydrogen bond with the oxygen atom 014 of riparin I, having a formation distance of $2.94 \AA$ A. A special case occurs with Lys199 residue, it performs electrostatic interaction of the cation- $\pi$ type with the A-ring (insert at Fig. 1) of riparin I (Fig. 7b).

On the central branch (Fig. 7F), Ser192, Lys195, Gln196, Leu238, Ile290, Ala291, and Glu292 residuesLeu198Trp214Leu238Val344Pro447Val455 are taking part in hydrophobic contributions of the interaction with riparin II. The Tyr150, Lys199, His242, and Arg257 residues make up hydrogen bonds with the molecule. The $\mathrm{OH}$ and $\mathrm{NH}$ group of the Tyr150 and Arg257 side chain form two hydrogen bonds with the 022 oxygen atom of riparin II, showing formation distances of 2.40 and $2.93 \AA$, respectively. This $\mathrm{O} 22$ atom presents the densest distribution of negative charge as can be seen in MEP of the molecule (Fig. S1B). The $\mathrm{NH}_{3}^{+}$and $\mathrm{NH}$ (position E1) group of Lys199 and His242 side chain make up two hydrogen bonds with the $\mathrm{O} 3$ oxygen atom of riparin II, having a formation distance of 2.98 and $2.84 \AA$, respectively.

On the right branch (Fig. 7G), Ser192, Lys195, Gln196, Lys199, Leu238, Val241, Leu260, Ile290, and Ala291 residuesLeu198 Trp214Leu238Val344Pro447Val455 are participating in hydrophobic interactions with the riparin III molecule. The Tyr150, His242 and Arg257 residues form hydrogen bonds with the ligand. The $\mathrm{OH}$ and $\mathrm{NH}$ group of the Tyr150 and Arg257 side chain makes up two hydrogen bonds with the $\mathrm{O} 22$ oxygen atom of ligand, presenting formation distances of 2.49 and $3.05 \AA$, respectively. The $\mathrm{NH}(\varepsilon 2)$ group of His242 side chain forms a hydrogen bond with the $\mathrm{O} 3$ oxygen atom of riparin III, having a formation distance of $2.91 \AA$.

From the LigPlot results, it is possible to see that hydrophobic interactions are the largest contribution in binding riparins to site I of HSA, with the following sequence: riparin I (ten residues), riparin III (eight residues) and riparin II (seven residues). However, the electrostatic interactions present a significant contribution to complex stabilization in the formation of hydrogen bonds. The HSA-riparin II complex has four hydrogen bonds while the interaction of the riparin I and III with HSA presents three. It is important to note that the amino acid residues of HSA involved in the binding with riparins are highly preserved, and Tyr150 and Arg257 residues are always present in the formation of hydrogen bonds with riparins, playing a key role in the ligands binding at site I of the protein.

\section{Conclusion}

The molecular mechanism of interactions between riparins and human serum albumin were exploited through fluorescence spectroscopy and computational methods. The endogenous fluorescence intensity of $\operatorname{Trp} 214$ was the key to monitor the interaction as a whole, making it possible to search for the quenching mechanism, binding sites, affinity index, and thermodynamic parameters. The results of the binding data analysis showed that all riparins accessed the same binding site (site I), however with differences in the affinity index, indicating that some specific feature may be related with the frame of riparin. Riparin I and II presented a slight difference in the value of the binding constant, which may be due to the presence of the first $\mathrm{OH}$ chemical group in the riparin II molecule. In the case of riparin III, the decrease in the binding constant was more pronounced when compared to riparin I and II, which again may be pointing to the addition of the second $\mathrm{OH}$ chemical group to the riparin structure. All these results have a direct relationship with the thermodynamic assays. For riparin I and II, the signals for $\Delta \mathrm{G}, \Delta \mathrm{H}$ are negative, while $\Delta \mathrm{S}$ positive. In terms of magnitude, the enthalpy contribution for riparin II, compared to riparin I, almost doubled in value being more likely to form hydrogen bonds. On the other hand, the value of entropy dropped almost half, which means that the contribution of non-specific interaction became less effective. The signal and magnitude changes of the entropic contribution for riparin III are related to its own molecular frame, more precisely at the B-ring (insert Fig. 1) which is the structure where the hydroxyl group hangs. The addition of the second $\mathrm{OH}$ group to riparin III shows how important is during the formation of the complex, therefore interfering in the affinity index. This may be linked to the capacity of riparin III to perform an intramolecular hydrogen bond, perceptible through the experimental bias responses and detailed by computational tools. In conclusion we suggest that the hydroxyl group modulated the interaction between riparin and human serum albumin. The next steps for future work are based on the synergistic approach using physical and computational tools. Molecular targets with a more specific profile than human albumin are of great importance from the point of view of human health and well-being.

Supplementary data to this article can be found online at http://dx. doi.org/10.1016/j.saa.2017.08.068.

\section{Acknowledgment}

The author CRC gratefully acknowledges a CAPES scholarship and professor Altair Benedito Moreira by the use of the fluorimetry equipment supported by Fapesp (Process 2014/22400-3).

\section{References}

[1] S.G. Dos Santos, K.F. Queiroga, A.M.F. De Oliveira, J.F. Tavares, S.J.C. Gutierrez, M.D.F.F.M. Diniz, J.M. Barbosa-Filho, M.S. Da Silva, Blood matrix effects for male and female Wistar rats, in simultaneous HPLC-UV determination of riparin i and III from Aniba riparia (Nees) Mez. (Lauraceae), Talanta 86 (2011) 233-240, http:// dx.doi.org/10.1016/j.talanta.2011.09.008.

[2] A. Quinet, R.H. Potsch Andreata, Lauraceae Jussieu na Reserva Ecológica de Macaé de Cima, 53, Município de Nova Friburgo, Rio de Janeiro, Brasil, Rodriguésia, 2002 59-121.

[3] C. Marques, Importância econômica da família Lauraceae Lindl, Floresta E Ambient. 8 (2001) 195-206

[4] R.O. Silva, S.R.B. Damasceno, I.S. Silva, V.G. Silva, C.F.C. Brito, A. Eder, A. Teixeira, G.B.L. Nunes, C.A. Camara, J.M.B. Filho, S.J.C. Gutierrez, R.A. Ribeiro, M.H.L.P. Souza, A.L.R. Barbosa, R.M. Freitas, J.V.R. Medeiros, Riparin A, a compound from Aniba riparia, attenuate the inflammatory response by modulation of neutrophil migration, Chem. Biol. Interact. 229 (2015) 55-63, http://dx.doi.org/10.1016/j.cbi.2015. 01.029 .

[5] J.M. Barbosa-Filho, M. Yoshida, O.R. Gottlieb, R. de C.S.B.C. Barbosa, A.M. Giesbrecht, M. Claudia M. Young, Benzoyl esters and amides, styrylpyrones and neolignans from the fruits of Aniba riparia, Phytochemistry 26 (1987) 2615-2617, http://dx.doi.org/ 10.1016/S0031-9422(00)83890-X

[6] U.V. Castelo-Branco, U.J.V. Castelo-Branco, G. Thomas, C.C. De Araújo, J.M. BarbosaFilho, Preliminary pharmacological studies on three benzoyl amides, constituents of Aniba riparia (Nees) mez (Lauraceae), Acta Farm. Bonaer. 19 (2000) 197-202.

[7] A.M.R. de Carvalho, N.F.M. Rocha, L.F. Vasconcelos, E.R.V. Rios, M.L. Dias, M.I.G. Silva, M.M. De França Fonteles, J.M.B. Filho, S.J.C. Gutierrez, F.C.F. De Sousa, Evaluation of the anti-inflammatory activity of riparin II (O-methil-N-2-hidroxi-benzoyl tyramine) in animal models, Chem. Biol. Interact. 205 (2013) 165-172, http://dx.doi. org/10.1016/j.cbi.2013.07.007.

[8] F.L.O. Araújo, C.T.V. Melo, N.F.M. Rocha, B.A. Moura, C.P. Leite, J.F. Amaral, J.M. Barbosa-Filho, S.J.C. Gutierrez, S.M.M. Vasconcelos, G.S.B. Viana, F.C.F. De Sousa, Antinociceptive effects of (O-methyl)-N-benzoyl tyramine (riparin I) from Aniba riparia (Nees) Mez (Lauraceae) in mice, Naunyn Schmiedeberg's Arch. Pharmacol. 380 (2009) 337-344, http://dx.doi.org/10.1007/s00210-009-0433-9.

[9] F.C.F. de Sousa, A.P. Monteiro, C.T.V. de Melo, G.R. de Oliveira, S.M.M. Vasconcelos, M.M. de França Fonteles, S.J.C. Gutierrez, J.M. Barbosa-Filho, G.S.B. Viana, Antianxiety effects of riparin I from Aniba riparia (Nees) Mez (Lauraceae) in mice, Phytother. Res. 19 (2005) 1005-1008, http://dx.doi.org/10.1002/ptr.1771.

[10] C.P.L. Teixeira, C.T.V. De Melo, F.L.O. De Araújo, A.M.R. De Carvalho, M.I.G. Silva, J.M. Barbosa-Filho, D.S. Macêdo, G.S. De Barros Viana, F.C.F. De Sousa, Antidepressantlike effect of riparin II from Aniba riparia in mice: evidence for the involvement of the monoaminergic system, Fundam. Clin. Pharmacol. 27 (2013) 129-137, http:// dx.doi.org/10.1111/j.1472-8206.2011.00973.x.

[11] C.T.V. de Melo, A.P. Monteiro, C.P. Leite, F.L.O. de Araújo, V.T.M. Lima, J.M. BarbosaFilho, M.M. de Franç Fonteles, S.M.M. de Vasconcelos, G.S. de Barros Viana, F.C.F. de Sousa, Anxiolytic-like effects of (O-methyl)-N-2,6-dihydroxybenzoyl-tyramine (riparin III) from Aniba riparia (Nees) Mez (Lauraceae) in mice, Biol. Pharm. Bull. 29 (2006) 451-454, http://dx.doi.org/10.1248/bpb.29.451.

[12] F.C.F. Sousa, C.T.V. Melo, A.P. Monteiro, V.T.M. Lima, S.J.C. Gutierrez, B.A. Pereira, J.M. Barbosa-Filho, S.M.M. Vasconcelos, M.F. Fonteles, G.S.B. Viana, Antianxiety and antidepressant effects of riparin III from Aniba riparia (Nees) Mez (Lauraceae) in mice, Pharmacol. Biochem. Behav. 78 (2004) 27-33, http://dx.doi.org/10.1016/j.pbb. 2004.01.019.

[13] R.M.R. Catão, J.M. Barbosa-Filho, E.D.O. Lima, M. do S.V. Pereira, T.A. Arruda, R.P.A. Miranda, Avaliação da atividade antimicrobiana e efeitos biológicos de riparinas sobre eliminação de resistência a drogas em amostras de Staphylococcus aureus, Rev. Bras. Anal. Clin. 42 (2010) 9-14.

[14] M. Dockal, D.C. Cater, F. Rüker, The three recombinant domains of human serum albumin, October 274 (1999) 29303-29310. 
[15] E.L. Gelamo, M. Tabak, Spectroscopic studies on the interaction of bovine (BSA) and human (HSA) serum albumins with ionic surfactants, Spectrochim. Acta A Mol. Biomol. Spectrosc. 56 (2000) 2255-2271.

[16] F. Zsila, Subdomain IB is the third major drug binding region of human serum albumin: toward the three-sites model, Mol. Pharm. 10 (2013) 1668-1682, http://dx. doi.org/10.1021/mp400027q.

[17] C.G.M. Heijnen, G.R.M.M. Haenen, F.A.A. van Acker, W.J.F. van der Vijgh, A. Bast, Flavonoids as peroxynitrite scavengers: the role of the hydroxyl groups, Toxicol. in Vitro 15 (2001) 3-6, http://dx.doi.org/10.1016/S0887-2333(00)00053-9.

[18] J. Xiao, M. Suzuki, X. Jiang, K. Yamamoto, F. Ren, M. Xu, Influence of B-ring hydroxylation on interactions of flavonols with bovine serum albumin influence of B-ring hydroxylation on interactions of flavonols with bovine serum albumin, Society (2008) 2-9, http://dx.doi.org/10.1021/jf7037295.

[19] O.L. Woodman, W.F. Meeker, M. Boujaoude, Vasorelaxant and antioxidant activity of flavonols and flavones: structure-activity relationships, J. Cardiovasc. Pharmacol. 46 (2005) 302-309, http://dx.doi.org/10.1097/01.fjc.0000175431.62626.07.

[20] Í.P. Caruso, J.M.B. Filho, A.S. De Araújo, F.P. De Souza, M.A. Fossey, M.L. Cornélio, An integrated approach with experimental and computational tools outlining the cooperative binding between 2-phenylchromone and human serum albumin, Food Chem. 196 (2016) 935-942, http://dx.doi.org/10.1016/j.foodchem.2015.10.027.

[21] J.R. Lakowicz, Principles of Fluorescence Spectroscopy, 2nd ed. Kluwer Academic Publisher/Plenum Press, New York, 1999.

[22] D. Wu, J. Yan, J. Wang, Q. Wang, H. Li, Characterisation of interaction between food colourant allura red AC and human serum albumin: multispectroscopic analyses and docking simulations, Food Chem. 170 (2015) 423-429, http://dx.doi.org/10. 1016/j.foodchem.2014.08.088.

[23] T. Wybranowski, M. Cyrankiewicz, B. Ziomkowska, S. Kruszewski, The HSA affinity of warfarin and flurbiprofen determined by fluorescence anisotropy measurements of camptothecin, Biosystems 94 (2008) 258-262, http://dx.doi.org/10.1016/j. biosystems.2008.05.034.

[24] M.J. Frisch, G.W. Trucks, H.B. Schlegel, G.E. Scuseria, M.A. Robb, J.R. Cheeseman, G. Scalmani, V. Barone, B. Mennucci, G.A. Petersson, H. Nakatsuji, M. Caricato, X. Li, H.P. Hratchian, A.F. Izmaylov, J. Bloino, G. Zheng, J.L. Sonnenberg, M. Hada, M. Ehara, K. Toyota, R. Fukuda, J. Hasegawa, M. Ishida, T. Nakajima, Y. Honda, O. Kitao, H. Nakai, T. Vreven, J.A. Montgomery, J. E.P. Jr., F. Ogliaro, M. Bearpark, J.J. Heyd, E. Brothers, K.N. Kudin, V.N. Staroverov, R. Kobayashi, J. Normand, K. Raghavachari, A. Rendell, J.C. Burant, S.S. Iyengar, J. Tomasi, M. Cossi, N. Rega, J.M. Millam, M. Klene, J.E. Knox, J.B. Cross, V. Bakken, C. Adamo, J. Jaramillo, R. Gomperts, R.E. Stratmann, O. Yazyev, A.J. Austin, R. Cammi, C. Pomelli, J.W. Ochterski, R.L. Martin, K. Morokuma, V.G. Zakrzewski, G.A. Voth, P. Salvador, J.J. Dannenberg, S. Dapprich, A.D. Daniels, O. Farkas, J.B. Foresman, J.V. Ortiz, J. Cioslowski, D.J. Fox, Gaussian 09, Revision A.02, 2009.

[25] S. Sugio, A. Kashima, S. Mochizuki, M. Noda, K. Kobayashi, Crystal structure of human serum albumin at 2.5 A resolution, Protein Eng. 12 (1999) 439-446, http://dx.doi.org/10.1093/protein/12.6.439.

[26] M.F. Sanner, Python: a programming language for software integration and development, J. Mol. Graph. Model. 17 (1999) 57-61.

[27] G.M. Morris, D.S. Goodsell, R.S. Halliday, R. Huey, W.E. Hart, R.K. Belew, A.J. Olson, Automated docking using a Lamarckian genetic algorithm and an empirical binding free energy function, J. Comput. Chem. 19 (1998) 1639-1662, http://dx.doi.org/10. 1002/(SICI)1096-987X(19981115)19:14<1639::AID-JCC10>3.0.CO;2-B.

[28] W.L. Delano, The PyMOL Molecular Graphics System, San Carlos, CA, USA, 2002.
[29] A.C. Wallace, R.A. Laskowski, J.M. Thornton, LIGPLOT: a program to generate schematic diagrams of protein-ligand interactions, Protein Eng. 8 (1995) 127-134, http://dx.doi.org/10.1093/nar/25.24.4940.

[30] Y. Yue, Q. Dong, Y. Zhang, X. Li, X. Yan, Y. Sun, J. Liu, Synthesis of imidazole derivatives and the spectral characterization of the binding properties towards human serum albumin, Spectrochim. Acta A Mol. Biomol. Spectrosc. 153 (2016) 688-703, http://dx.doi.org/10.1016/j.saa.2015.09.023.

[31] Y. Ni, R. Zhu, S. Kokot, Competitive binding of small molecules with biopolymers: fluorescence spectroscopy and chemometrics study of the interaction of aspirin and ibuprofen with BSA, Analyst 136 (2011) 4794, http://dx.doi.org/10.1039/ c1an15550d.

[32] S. Bi, L. Ding, Y. Tian, D. Song, X. Zhou, X. Liu, H. Zhang, Investigation of the interaction between flavonoids and human serum albumin, J. Mol. Struct. 703 (2004) 37-45, http://dx.doi.org/10.1016/j.molstruc.2004.05.026.

[33] M. Van De Weert, L. Stella, Fluorescence quenching and ligand binding: a critical discussion of a popular methodology, J. Mol. Struct. 998 (2011) 145-150, http://dx.doi. org/10.1016/j.molstruc.2011.05.023.

[34] P.D. Ross, S. Subramanian, Thermodynamics of protein association reactions: forces contributing to stability, Biochemistry 20 (1981) 3096-3102, http://dx.doi.org/10. 1021/bi00514a017.

[35] Í.P. Caruso, W. Vilegas, M.A. Fossey, M.L. Cornélio, Exploring the binding mechanism of Guaijaverin to human serum albumin: fluorescence spectroscopy and computational approach, Spectrochim. Acta A Mol. Biomol. Spectrosc. 97 (2012) 449-455, http://dx.doi.org/10.1016/j.saa.2012.06.043.

[36] G. Sudlow, D.J. Birkett, D.N. Wade, The characterization of two specific drug binding sites on human serum, Mol. Pharmacol. 11 (1975) 824-832.

[37] G. Zhang, Y. Ma, Mechanistic and conformational studies on the interaction of food dye amaranth with human serum albumin by multispectroscopic methods, Food Chem. 136 (2013) 442-448, http://dx.doi.org/10.1016/j.foodchem.2012.09.026.

[38] U. Kragh-Hansen, V.T.G. Chuang, M. Otagiri, Practical aspects of the ligand-binding and enzymatic properties of human serum albumin, Biol. Pharm. Bull. 25 (2002) 695-704, http://dx.doi.org/10.1248/bpb.25.695.

[39] K. Yamasaki, V.T.G. Chuang, T. Maruyama, M. Otagiri, Albumin-drug interaction and its clinical implication, Biochim. Biophys. Acta, Gen. Subj. 1830 (2013) 5435-5443, http://dx.doi.org/10.1016/j.bbagen.2013.05.005.

[40] D. Beckett, Measurement and Analysis of Equilibrium Binding Titrations: A Beginner's Guide, 1st ed. Elsevier Inc., 2011 (doi:http://dx.doi.org/10.1016/B9780-12-381268-1.00001-X).

[41] W. Bujalowski, M.J. Jezewska, Accessing thermodynamics of the unmodified macromoleculeligand interactions through spectroscopic titrations of fluorescent analogs, Macromolecular Competition Titration Method, 1st ed.Elsevier Inc., 2011 (doi:http://dx.doi.org/10.1016/B978-0-12-381268-1.00002-1).

[42] A.K. Bordbar, A.A. Saboury, A.A. Moosavi-Movahedi, The shapes of scatchard plots for systems with two sets of binding sites, Biochem. Educ. 24 (1996) 172-175, http://dx.doi.org/10.1016/0307-4412(95)00122-0.

[43] M. Daune, Structures in motion, Molecular Biophysics, Oxford University Press, New York, 1999.

[44] K.E. van Holde, W.C. Johnson, P.S. Ho, Principles of physical biochemistry, Libr Congr. Cat. Data. 36 (1998) 657, http://dx.doi.org/10.1021/ed076p474.1.

[45] A.D.S. Marques, C. Zheng, C.T. Lin, Y. Takahata, M. Barbosa-Filho, S.J.C. Gutierrez Electronic and structural effects in muscular relaxants: riparin I and riparin III, J. Mol. Struct. 753 (2005) 13-21, http://dx.doi.org/10.1016/j.molstruc.2005.06.018. 